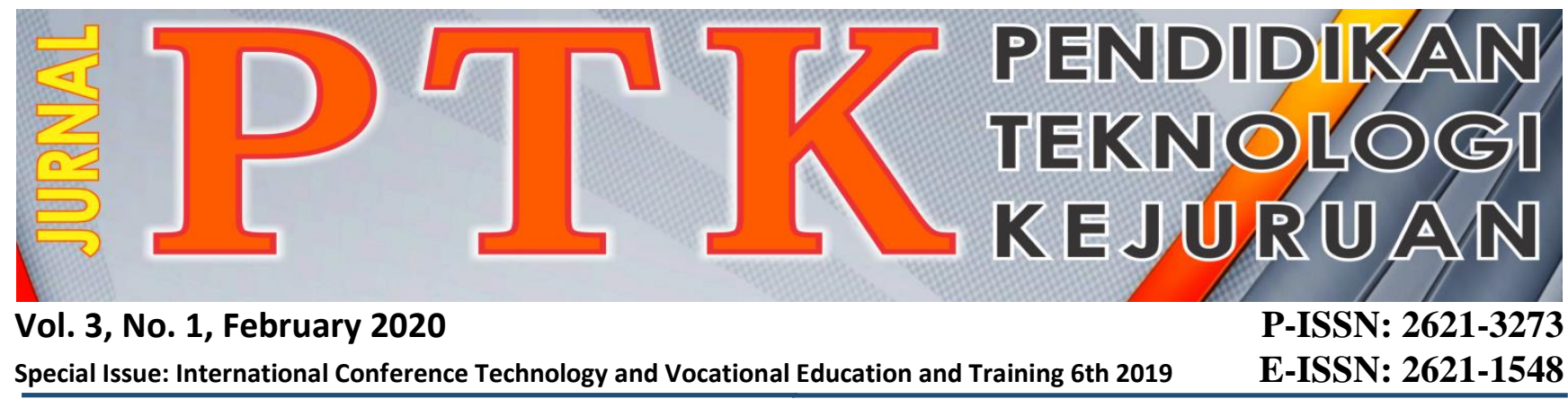

\title{
NEEDS ANALYSIS IN LEARNING MEDIA DEVELOPMENT BASED ON AUGMENTED REALITY (AR) FOR COMPUTER NETWORK INSTALLATION COURSES
}

\author{
Akrimullah Mubai, Kasman Rukun, Giatman, and Edidas \\ Faculty of Engineering, Universitas Negeri Padang \\ *Corresponding author, e-mail: akrimullah@student.unp.ac.id
}

\begin{abstract}
This needs analysis research consists of field studies and literature studies. Where the purpose of this research is; 1) description of student achievement values and learning processes, 2) the uses and constraints faced by students in the use of learning media Computer Network Installation, 3) formulation of instructional media needed in learning computer network installation. This research belongs to the type of qualitative descriptive research. The subjects of this study were 29 students of Informatics Engineering Education study programs and 2 lecturers of computer network installation courses. Data obtained using a questionnaire and analysis qualitatively through stages; arranging, tabulating, analyzing qualitative data and making interpretations of the results of the analysis according to the problems and objectives of the study which then makes conclusions. The results showed that; 1 ) there are still many students who have not reached the score above the minimum criteria and fail in carrying out the practicum process, 2 ) the biggest obstacle faced by students in implementing Computer Network Installation learning is the limitations of using instructional media that are less effective to support independent learning, 3) the media that need developed for learning Computer Network Installation which is learning media based on Augmented Reality (AR).
\end{abstract}

Keywords: Requirement Analysis, Qualitative Descriptive, Learning Media, Computer Network Installation, Augmented Reality (AR)

Copyright $\odot 2020$ JPTK. All rights reserved

\section{INTRODUCTION}

Education is an important indicator for the progress of a nation in supporting the development of character and competence of national generations. The most common problem in education is the low achievement of student learning outcomes [1]. This is caused by internal factors and external factors of students. Internal factors come from within the student which is psychological, while external factors are all aspects that come from outside the student [2][3].

External factors that greatly affect learning outcomes include learning media. Learning media is an intermediary carrying a message or information that is instructional or contains teaching purposes between the source and receiver [4]. Effective and efficient learning media will determine whether or not learning information is conveyed to students so that it affects students' learning outcomes.

Good learning media will be able to encourage students to learn independently so that studentcentred learning can be achieved [5]. But in its implementation, there are still many learning media that are still not good. As preliminary observations, the researcher conducted an investigation into the academic community of Computer and Informatics Engineering Education Department of Electronic Engineering, Faculty of Engineering, State University of Padang, located in West Sumatra, Indonesia. Observations were made on students and lecturers who carry out computer network installation courses. The Computer Network Installation course is a practical course that uses instructional media in the form of lab sheets and practical tools directly.

The use of instructional media for Computer Network Installation is considered to be less effective and efficient because this media does not support students to learn independently. Problems occur when learning is carried out outside the laboratory where practicum may not be used outside the laboratory. Meanwhile, to rely on lab-sheets it is not enough to be able to explain the material that is abstract and detailed because the lab-sheets only contain 
explanations with narrative text and 2D drawings. This has an impact on the number of students who fail to carry out the practicum, such as the results of the installation of the network media making cable of Unshiled Twister Pair (UTP), which can be seen in table 1.

Table 1. The success rate of several class $2 \mathrm{~F} 1.2$ practicums for computer network installation

\begin{tabular}{|c|c|c|c|c|}
\hline \multirow{3}{*}{$\begin{array}{l}\text { Learning } \\
\text { Materials }\end{array}$} & \multicolumn{4}{|c|}{ Number of Students } \\
\hline & \multicolumn{2}{|c|}{2 F1 } & \multicolumn{2}{|c|}{$2 \mathrm{~F} 2$} \\
\hline & $\begin{array}{c}\text { Succe- } \\
\text { ssful }\end{array}$ & Failed & Successful & Failed \\
\hline Network Media & 7 & 6 & 9 & 7 \\
\hline $\begin{array}{l}\text { Local Area } \\
\text { Network }\end{array}$ & 10 & 3 & 11 & 5 \\
\hline $\begin{array}{l}\text { Netmask and } \\
\text { Subnetting }\end{array}$ & 8 & 5 & 8 & 8 \\
\hline
\end{tabular}

The results of the success rates of several practicums for a computer network installation course found that $60.92 \%$ succeeded or there were 5 to 6 students failing each practicum in class $2 \mathrm{~F} 1.2$, so they had to repeat the practicum. The repetition of this installation makes the need for practicum material increase due to the material used is a disposable material, even though the availability of practicum material is very limited. This also has an impact on the achievement of the student's low practical score. The low achievement of student grades in the computer network installation courses can be seen in table 2.

Table 2. Learning outcomes computer network installation course for class $2 \mathrm{~F} 1.2$ students in the January-June 2019 semester

\begin{tabular}{cccccc}
\hline & \multicolumn{5}{c}{ College Student } \\
Value & $\mathbf{2 F 1}$ & $\mathbf{2 F 2}$ & Value & $\mathbf{2 F 1}$ & $\mathbf{2 F 2}$ \\
A & 1 & 6 & C & 0 & 0 \\
A- & 2 & 5 & C- & 0 & 0 \\
B+ & 2 & 2 & D+ & 0 & 0 \\
B & 0 & 0 & D & 0 & 0 \\
B- & 7 & 0 & D- & 0 & 0 \\
C + & 1 & 1 & E & 0 & 2 \\
Amount & $\mathbf{1 3}$ & $\mathbf{1 4}$ & Amount & $\mathbf{0}$ & $\mathbf{2}$ \\
\hline
\end{tabular}

The learning outcomes for the Computer Network Installation course found that $37.93 \%$ of the total 29 students in grade $2 \mathrm{~F} 1.2$ scored below the minimum criteria. This needs to be changed to improve the number of low student grades. One very important change is implemented in the learning media. Changes in learning media can be done by creating new media or developing existing media. The development of instructional media is considered important because of the needs of students for learning media that support independent learning so that they no longer depend on the use of tools and practical materials that can only be used in the laboratory.

The development of learning media must be able to present practicum tools and materials even though it is in a virtual form in learning. So that learning can be done independently outside the laboratory, which is then expected to be able to minimize failures in the practice and improve student learning outcomes.

Development of instructional media in minimizing these problems can utilize augmented reality (AR) technology. Augmented reality (AR) technology is a technology that combines real and virtual objects in a real environment, runs interactively in real-time, and there is integration between objects in three dimensions, namely virtual objects integrated into the real world [6].

Augmented reality (AR) technology uses objects as markers to display $3 \mathrm{D}$ visuals as well as videos, so this technology is able to display virtual 3D tools and materials and simulation videos for learning [7]-[9]. While the markers needed by augmented reality (AR) technology can be in the form of cards or paper, so they can be combined with existing lab-sheets [8].

Augmented reality (AR) technology is made in a mobile application such as Android or IOS, so this augmented reality (AR) technology can be used on smartphone devices [7] [9]. Almost every student of Informatics and Computer Study Program at Padang State University in 2019 already has their own smartphone, so with the application of augmented reality (AR) based learning media the optimization of smartphone functions for learning increases. Utilizing a smartphone in learning will be able to support independent learning that can be done anywhere.

Many studies have been conducted in the development of learning media based on augmented reality (AR) technology which results in a good chance for the learning process and outcomes [9][13]. Seeing the many advantages of augmented reality (AR) technology if developed into learning media, researchers want to conduct research on needs analysis students for the application of augmented reality (AR) technology in learning media for Computer Network Installation.

\section{METHODOLOGY}

This research is a preliminary study of the stages in the pre-research procedure with research and development (R\&D) methods. This research is limited to the analysis of needs derived from initial observations in the field and also a study of relevant literature. The research subjects were 29 students of the Informatics Engineering Study Program class of 2019 and 2 lecturers of computer network installation lecturers. 
The research method used in this study is a descriptive method. Qualitative research methods are research methods based on the philosophy of postpositivism, used to examine the natural conditions of objects, (as opposed to experiments) where researchers as key instruments, sampling data sources is done purposively and snow-bally, collecting techniques with triangulation (combined), data analysis is inductive/qualitative, and qualitative research results emphasize meaning rather than generalization [14].

Data will be obtained from the use of questionnaire analysis of lecturer needs and student needs. The data obtained is processed in four stages. The first stage is compiling data from questionnaire distribution. The second stage is the tabulation of data to see the class, nature, type, and frequency of the data. Data tabulation aims to facilitate reading, categorizing and analyzing data.

In the third stage, qualitative analysis, where data will be broken down to be linked to information related to the research focus. The fourth stage is making interpretations of the results of the analysis of the problems and questions of researchers which then drawn a conclusion.

\section{RESULT AND DISCUSSION}

The results of the analysis of the needs of augmented reality (AR) based learning media for the Computer Network Installation course were obtained through observation. Observations made to 29 students of the study program in informatics and computer engineering education and 2 lecturers of Computer Network Installation courses in the January-June 2019 semester. From the observations get the results of the research presented in table 3 .

The results of the analysis of lecturers' needs for augmented reality (AR) based learning media for Computer Network Installation courses show that there are still many student learning outcomes below the minimum completeness criteria value. More than $37 \%$ of students who scored below the minimum completeness criteria, this is partly due to the frequent failure of students in the practice.

Student practice failures reached an average of $39.08 \%$ in each lesson. This failure is caused by many factors including learning media that do not support independent learning, so students rely solely on learning in the laboratory. So, therefore, a study was conducted on students about the problems and expectations of learning media Computer Network Installation that they need. The results of research on students, the data obtained are shown in table 4.

Table 3. The results of the analysis of the needs of lecturers on learning media

\begin{tabular}{|c|c|c|c|}
\hline & Question Analysis & Identification of problems & Conclusion \\
\hline 1. & $\begin{array}{l}100 \% \text { of lecturers answer students who get a score that } \\
\text { does not meet the minimum completeness criteria of } \\
\text { more than } 37 \% \text { of the total number of students }\end{array}$ & $\begin{array}{l}\text { Lecturers are aware that there are still } \\
\text { many students who have not received a } \\
\text { score above the minimum completeness } \\
\text { criteria }\end{array}$ & $\begin{array}{l}\text { The low student } \\
\text { learning outcomes }\end{array}$ \\
\hline 2. & $\begin{array}{c}100 \% \text { of lecturers answered that at least } 39,08 \% \text { of } \\
\text { students failed in practicum implementation or about } 5 \text { to } \\
6 \text { people who fail in each practice. }\end{array}$ & $\begin{array}{l}\text { Lecturers are aware that there are still } \\
\text { many students who have not been able } \\
\text { to complete the practice well }\end{array}$ & $\begin{array}{l}\text { The low achievement of } \\
\text { student practicum } \\
\text { success }\end{array}$ \\
\hline 3. & $\begin{array}{l}50 \% \text { of lecturers answered difficulties in conveying } \\
\text { learning information with learning media in the form of } \\
\text { image and text-based lab sheets. }\end{array}$ & $\begin{array}{l}\text { Learning media that are less helpful to } \\
\text { lecturers in learning }\end{array}$ & $\begin{array}{l}\text { Less informative media } \\
\text { for learning }\end{array}$ \\
\hline 4. & $\begin{array}{l}100 \% \text { of lecturers answered learning media in the form of } \\
\text { image and text-based worksheets did not support students } \\
\text { to learn independently }\end{array}$ & $\begin{array}{l}\text { Less effective learning media in } \\
\text { supporting independent learning } \\
\text { students }\end{array}$ & $\begin{array}{l}\text { Learning media that do } \\
\text { not yet support } \\
\text { independent learning }\end{array}$ \\
\hline 5. & $\begin{array}{c}50 \% \text { of the lecturers answered that the job sheet learning } \\
\text { media has not been able to explain abstract learning } \\
\text { material }\end{array}$ & $\begin{array}{l}\text { Learning media in the form of job } \\
\text { sheets still use } 2 \mathrm{D} \text { drawings and text } \\
\text { that are less attractive }\end{array}$ & $\begin{array}{l}\text { Need to improve } \\
\text { learning media interface }\end{array}$ \\
\hline 6. & $\begin{array}{l}50 \% \text { of the lecturers answered that the presentation of } \\
\text { learning materials cannot rely solely on media lab sheets } \\
\text { without the support of the practicum directives }\end{array}$ & $\begin{array}{l}\text { Learning media cannot be used as a } \\
\text { single learning source }\end{array}$ & $\begin{array}{l}\text { Dependence on learning } \\
\text { media used }\end{array}$ \\
\hline 7. & $\begin{array}{l}100 \% \text { of the lecturers answered that there was a need to } \\
\text { improve the quality of learning media in the form of lab } \\
\text { sheets for Computer Network Installation courses }\end{array}$ & $\begin{array}{l}\text { The quality of instructional media in the } \\
\text { form of job sheets for Computer } \\
\text { Network Installation courses needs to } \\
\text { be improved }\end{array}$ & $\begin{array}{l}\text { The need to improve the } \\
\text { quality of learning } \\
\text { media }\end{array}$ \\
\hline
\end{tabular}

Table 4. Results of analysis of student needs for media learning courses Computer Network Installation

Question Analysis 
2.

3.

4

5 .

6.

$52 \%$ of students answered the difficulties in carrying out the practicum because the learning media used did not support independent learning

$69 \%$ of students answered the difficulty in understanding practicum material with learning media in the form of $2 \mathrm{D}-\mathrm{based}$ lab sheets

$38 \%$ of students answered the difficulty in learning practicum material with the lab sheet media outside the laboratory because the media supporting the lab sheet in the form of practical tools cannot be used $69 \%$ of students want user-friendly and mobile learning media that they can use anywhere $45 \%$ of students want a learning media that is interactive and practical

$48 \%$ of students want learning media that is able to present practical tools and materials in the form of virtual 3D on their smartphones

7. $76 \%$ of students want a learning media that is able to present practicum stages in the form of videos on their smartphones

The results of the analysis of student needs showed that $52 \%$ of students had difficulty in carrying out the practicum in Computer Network Installation lessons. This difficulty is caused by many factors, including learning media factors. Learning media Computer Network Installation uses image-based 2D text sheets that are less mobile, interactive and support independent learning.

Learning media needed by students are learning media that are able to attend to learning needs such as practical tools wherever they learn. This, of course, requires media that is capable of using mobile and virtual 3D technology. Media that is able to use mobile and virtual technology is media that uses Augmented Reality (AR) technology.

Augmented Reality (AR) technology is able to visualize learning needs in the form of 3D objects, where these 3D objects can be developed in the form of animation or video. For this reason, it is necessary to develop learning media for Computer Network Installation that requires Augmented Reality (AR) technology based on needs analysis. Analysis of these needs is $100 \%$ the needs of lecturers to improve the quality of learning media and $76 \%$ of student needs for learning media that are mobile, interactive and support independent learning with practical videos.

\section{CONCLUSION}

Based on the preliminary study and the results of the study, the objectives expected from this study produce conclusions, namely; 1) There are still many students who have not reached the score above the minimum criteria and fail in carrying out the practicum process, 2) The biggest obstacle faced by students in implementing Computer Network Installation learning is the limitations of using instructional media that are less effective to support independent learning, 3) Media that need developed in learning Computer Network Installation, which is learning media based on Augmented Reality (AR).

\section{REFERENCES}

[1] Sari, M. M., Taufik, T., \& Yusri, Y. Peran Guru Bk/Konselor dan Guru Mata Pelajaran dalam Meningkatkan Motivasi Belajar Siswa yang Memperoleh Hasil Belajar Rendah. Konselor, 3(2), 59-66. 2016.

[2] Ardila, A., \& Hartanto, S. Faktor yang mempengaruhi rendahnya hasil belajar matematika siswa mts iskandar muda batam. PYTHAGORAS: Jurnal Program Studi Pendidikan Matematika, 6(2). 2017.

[3] Slameto. Belajar dan Faktor-Faktor yang Mempengaruhinya. Jakarta: PT Rineka Cipta. 2013.

[4] Arsyad, Azhar. Media Pembelajaran. Jakarta: PT Raja Grafindo Persada. 2011.

[5] Nurseto, T. Membuat media pembelajaran yang menarik. Jurnal Ekonomi dan Pendidikan, 8(1). 2011.

[6] Roedavan, Rickman. Unity Tutorial Game Engine: Informatika. 2014.

[7] Adami, F. Z., \& Budihartanti, C. Penerapan Teknologi Augmented Reality pada Media Pembelajaran Sistem Pencernaan Berbasis Android. Jurnal Teknik Komputer, 2(1), 122131. 2016.

[8] Kamelia, L. Perkembangan Teknologi Augmented Reality Sebagai Media Pembelajaran Interaktif Pada Mata Kuliah Kimia Dasar. Jurnal Istek, 9(1). 2015.

[9] Hamzah, S., \& Kurniadi, D. Pengembangan Media Pembelajaran Perangkat Keras Jaringan Berbasis Augmented Reality Pada Platform Android. Jurnal Vokasional Teknik Elektronika dan Informatika, 7(3), 146-157. 2019.

[10] Pambudi, K. H. B., Buchori, A., \& Aini, A. N. Pengembangan Media Pembelajaran Berbasis Android Menggunakan Augmented Reality Pada Materi Bangun Ruang Sisi Datar. Jurnal Pendidikan Matematika dan Sains, 6(1), 6169. 2018. 
[11] Mahpudin, A., \& Puadi, E. F. W. Rancang Bangun Augmented Reality (AR) Berbasis Android Untuk Pengembangan Media Pembelajaran Fisika. In Prosiding Seminar Nasional \& Internasional (Vol. 1, No. 1). 2018.

[12] Febrianti, R. Pengembangan Media Pembelajaran Berbasis Augmented Reality Pada Kompetensi Dasar Memahami Rangkaian Multiplexer, Decoder, Flip-Flop Dan Counter Kelas X Smk Negeri 2 Surabaya. IT-EDU, 1(01). 2016.

[13] Alfian, A., Hamid, M., \& Suhardi, I. Pengembangan Media Pembelajaran Aplikasi Augmented Reality Berbasis Android Menggunakan Unity untuk Pembelajaran Struktur Atom Senyawa Organik Hidrokarbon. Indonesian Journal of Educational Studies, 21(2). 2019.

[14] Sugiyono. Metode Penelitian Kuantitatif Kualitatif dan $R \& D$. Bandung: Alfabeta. 2012.

[15] S. Syahril, N. Jalinus, R. A. Nabawi, and Y. Arbi, "The Create Skills of Vocational Students to Design a Product: Comparison Project Based Learning Versus Cooperative Learning-Project Based Learning," Adv. Soc. Sci. Educ. Humanit. Res., vol. 299, no. 5th UPI International Conference on Technical and Vocational Education and Training (ICTVET 2018) The, pp. 316-320, 2019. 